24 hours); (2) because of the extreme suggestibility of patients with chronic disability due to neurological disease, especially multiple sclerosis; and ( 3 ) because many of the participants had previously co-operated in trials of various treatments for multiple sclerosis conducted in this department in the past.

These patients were familiar with the double-blind technique and were predictably anxious about taking new drugs. This was highlighted by the fact that of the nine patients complaining of side effects eight experienced them during the first half of the trial. None the less the 23 patients on average improved to a greater extent on baclofen than on the placebo and the difference between the improvements was significant at the 5\% level. This taken in conjunction with the absence of serious side effects, particularly intolerable somnolence, justifies extended studies of baclofen, perhaps including controlled trials against spasmolytic drugs currently in use.

Supplies of baclofen were made available by Ciba Laboratories, Horsham, Sussex. We wish to acknowledge with gratitude the ready co-operation of Dr. M. K. Flood, of Ciba Laboratories, at all times during the course of the trial. We also wish to thank Professor J. N. Walton, Dr. D. A. Shaw, and Dr. I. B. Foster, who referred some of the patients taking part. Secretarial facilities in the depart- ment of neurology, Royal Victoria Infirmary, were financed by the Multiple Sclerosis Society of Great Britain and Northern Ireland to whom we also wish to express our thanks.

AdDENDUM.-One of us (P.H.) has now treated seven patients with severe spastic paraparesis with baclofen for periods up to six months. In each case there has been a satisfactory reduction in spasticity without untoward side effects, though one man had to stop taking the drug because of an associated increase in leg weakness.

\section{References}

Ashworth, B. (1964). Practitioner, 192, 541.

Barwick, D. D., and Hudgson, P. (1967). Unpublished observations.

Birkmayer, W., Danielczynk, W., and Weiler, G. (1967). Wiener medizinische Wochenschrift, 117, 7 .

Cook, J. B., and Nathan, P. W. (1967). Fournal of the Neurological Sciences, 5,33 .

Curtis, D. R., and Watkins, J. C. (1965). Pharmacological Reviews, 17, 347.

Jones, R. F., Burke, D., Marosszeky, J. E., and Gillies, J. D. (1970). fournal of Neurology, Neurosurgery and Psychiatry, 33, 464.

Lancet, 1970, 2, 918.

Nathan, P. W. (1959). Lancet, 2, 1099.

Pedersen, E., Arlien-S $\phi$ borg, P., Grynderup, V., and Henriksen, O. (1970). Acta Neurologica Scandinavica, 46, 257.

\title{
Prenatal Diagnosis of Tay-Sachs Genotypes
}

\author{
RUTH NAVON， BARUCH PADEH
}

British Medical fournal, 1971, 4, 17-20

\section{Summary}

Hexosaminidase activity was determined in cultured and uncultured amniotic fluid cells taken from seven pregnant women who had previously given birth to infants with Tay-Sachs disease. Complete deficiency of hexosaminidase $A$ was found in one case, indicating a TaySachs fetus. The diagnosis was confirmed on examination of various tissues after therapeutic abortion. Of the other six cases three were considered heterozygous and three homozygous normal. These diagnoses were confirmed postnatally on examination of cord blood leucocytes, peripheral leucocytes, and urine. The activity of hexosaminidase $A$ is appreciably decreased in dead cells and hence in uncultured amniotic fluid cells. Hence reliable identification in utero of the three genotypes may be achieved only by examining the cultured living amniotic cells.

\section{Introduction}

Tay-Sachs disease is a lipid-storage disease inherited as an autosomal recessive trait and is invariably fatal. The ganglioside $\mathrm{GM}_{2}$ accumulates in the central nervous system and to a lesser extent in other tissues, including cultured skin fibroblasts. A complete absence of $\beta-\mathrm{D}-N$-acetylhexos-aminidase $\mathrm{A}$ in tissues of Tay-Sachs patients was found by Okada and O'Brien (1969), whereas both forms A and B of the enzyme are found in

\footnotetext{
Department of Human Genetics, Tel-Aviv University Medical School and Tel-Hashomer Hospital, Israel RUTH NAVON, M.SC., Research Biochemist BARUCH PADEH, M.D., Associate Professor of Medicine
}

normal individuals (Robinson and Stirling, 1969). Obligatory heterozygotes showed intermediate levels of hexosaminidase A, between those of patients with Tay-Sachs disease and normal controls (Friedland et al., 1970; O'Brien et al., 1970; Padeh and Navon, 1971; Navon and Padeh, 1971).

Hexosaminidase $A$ and $B$ have been found also in amniotic fluid cells of normal individuals (Okada and O'Brien, 1969; Rattazzi and Davidson, 1970; Schneck et al., 1970; Padeh and Navon, 1971). This enables one to make a prenatal diagnosis of the disorder since an affected fetus will probably have a deficiency of hexosaminidase $\mathrm{A}$ in the amniotic cells originating from its skin.

Schneck et al. (1970) reported one case of Tay-Sachs disease diagnozed during the second trimester of pregnancy (18 weeks). They showed in this case an absence of hexosaminidase A activity in cultured and uncultured amniotic fluid cells by acryamide-gel electrophoresis. The diagnosis was confirmed by showing a deficiency of form $\mathrm{A}$ of $\mathrm{N}$-acetylhexosaminidase in the liver and brain of the abortus.

A false-positive diagnosis was reported by Rattazzi and Davidson (1970). Using an electrophoretic method of assaying hexosaminidase from an extract of uncultured amniotic cells, they showed the absence of hexosaminidase band A, whereas the aborted fetus and subsequently the cultured amniotic cells had a normal ratio of hexosaminidase $\mathrm{A}$ and $\mathrm{B}$.

The purposes of this paper are to report and to discuss our experience in identification of the various genotypic possibilities with regard to Tay-Sachs disease by assaying the activity of hexosaminidase $\mathrm{A}$ after heat inactivation.

\section{Patients and Methods}

Amniotic fluid was obtained by transabdominal puncture from seven pregnant women who had previously given birth to Tay-Sachs disease offspring and from 10 other pregnant women who served as controls. Amniocentesis was performed 
usually during the 18th to 20 th week of pregnancy, but in two cases in week 25 and 28 .

Samples of $10-20 \mathrm{ml}$ of fluid were centrifuged at $200 \mathrm{~g}$ and the cells pellet divided into two parts: one was rinsed twice with $5 \mathrm{ml}$ of saline, dispersed in $2 \mathrm{ml}$ of $0.05 \mathrm{M}$ citrate buffer $\mathrm{pH} 5.0$ containing $0.1 \%$ bovine serum albumin, and then disrupted by freezing and thawing four times. After centrifugation for 30 minutes at $10,000 \mathrm{~g}$ the supernatant was used for assaying hexosaminidase activity.

The second part of the cells were cultured in F-10 culture medium with $30 \%$ fetal calf serum (Nadler, 1968). After three weeks there were sufficient cells for the determination of hexosaminidase. The cells were removed by trypsination and rinsed twice with $5 \mathrm{ml}$ of saline. The rinsing was performed owing to the fact that fetal calf serum was found to contain hexosaminidase A (Navon, unpublished data). The cells were dispersed in $2 \mathrm{ml}$ of $0.05 \mathrm{M}$ citrate buffer $\mathrm{pH} 5$ containing $0.1 \%$ bovine serum albumin, and then the extract solution was prepared for the hexosaminidase determination in the same way as the uncultured cells.

Hexosaminidase A and B differ markedly in their heat stability (Robinson and Stirling, 1969). Since hexosaminidase $A$ is labile to heating at $50^{\circ} \mathrm{C}$, whereas $B$ retains most of its activity, triplicates of the enzyme extract were incubated at $50^{\circ} \mathrm{C}$ for $0,1,2,3$, and 4 hours as described previously (Padeh and Navon, 1971), and the aliquotes were kept frozen till assayed. For determining hexosaminidase activity $0.2 \mathrm{ml}$ of $0.250 \mathrm{mM}$ 4-methyl-umbelliferyl- $N$-acetylglucosamine in 0.05 $\mathrm{M}$ citrate buffer $\mathrm{pH} 4.5$ and $0.1 \%$ bovine serum albumin was added to $0.1 \mathrm{ml}$ of the enzyme extract and incubated at $37^{\circ} \mathrm{C}$ for 30 minutes. The hydrolysis of the synthetic substrate was terminated by $0.8 \mathrm{ml}$ of $0.2 \mathrm{M}$ sodium hydroxide glycine buffer $\mathrm{pH}$ 10.6. The released 4-methyl-umbelliferone was measured in an Aminco Bowman spectrofluorometer at excitation wavelength $365 \mathrm{~nm}$ and an emission wavelength of $448 \mathrm{~nm}$. The estimation of hexosaminidase A activity was based on the inactivation of form A during heating and all values obtained at zero time were regarded as $100 \%$. Hexosaminidase A activity was calculated by subtracting the activity measured after three hours of incubation at $50^{\circ} \mathrm{C}$ from the total activity at zero time. The determination of hexosaminidase A activity in leucocytes and urine was done as previously described (Padeh and Navon, 1971; Navon and Padeh, 1971). Since the total activity of hexosaminidase showed a pronounced variability in all substances analysed only percentages of the total are given in the tables.

The amniotic cells were stained for viability with trypan blue $0.2 \%$ final concentration to estimate the proportion of viable cells to dead ones before the determination of hexosaminidase activity. This procedure was done three times. Once when obtaining the amniotic fluid, the second time to the cells that were floating in the medium after cultivating, and the third time to the cultured cells.

Starch-gel electrophoresis was performed as described previously (Padeh and Navon, 1971). The gel contained $30 \mathrm{~g}$ of electrostarch in $250 \mathrm{ml}$ of $5 \mathrm{mM}$ citrate phosphate buffer pH 6.0 . The electrode buffer was $0.04 \mathrm{M}$ citrate $\mathrm{pH} 6.0$. The potential gradient of $5 \mathrm{v} / \mathrm{cm}$ applied for 16 hours at $+4^{\circ} \mathrm{C}$. The gel was then incubated with 4-methyl-umbelliferyl- $\mathrm{N}$-acetylglucosamine for 45 minutes at $37^{\circ} \mathrm{C}$ and then sprayed with sodium hydroxide glycine buffer $\mathrm{pH} 10 \cdot 6$. The fluorescence regions were located by using ultraviolet light.

Gangliosides were extracted from brain tissue as described by Gatt and Berman (1963) from a normal aborted fetus (22 week), an aborted fetus (23 week) judged to have been affected with Tay-Sachs disease, a child with Tay-Sachs disease (18 month), and a normal child (5 years). The crude brain gangliosides $(100 \mu \mathrm{g})$ were spotted at each application point for thinlayer chromatography. The developing solvent was chloroform/ methanol/2N $\mathrm{NH}_{4} \mathrm{OH}(60: 35: 8)$. The plate was developed for one hour and then dried at $110^{\circ} \mathrm{C}$. The gangliosides were visualized with either resorcinol spray or, for the quantitative analysis, with iodine. The bands were scraped into Pyrex tubes and the contents were analysed for sialic acid as described by Svennerholm (1957).

\section{Results}

Hexosaminidase A activities calculated as a percentage of the total activity of the enzyme in cultured and uncultured amniotic cells and postnatally in leucocytes and urine of seven cases are summarized in Table I.

In the first six pregnancies hexosaminidase A activity of more than $20 \%$ of the total activity was found in both cultured and uncultured amniotic cells, indicating the absence of TaySachs disease. In all of them the activities of hexosaminidase A found postnatally in cord blood leucocytes, in peripheral leucocytes, and in urine were comparable to those found in cultured amniotic cells which confirmed the absence of TaySachs disease. In one patient (Case 7) there was almost a complete absence of hexosaminidase $\mathrm{A}$ activity in cultured and uncultured amnion cells, indicating a Tay-Sachs fetus. This pregnancy was subsequently terminated. No activity of hexosaminidase A was detected in the brain, spleen, skin, and skin fibroblasts of this abortus. These results are compared with those of a normal aborted fetus (Fig. 1).

Using starch-gel electrophoresis two components of the enzyme appeared in the homogenates of liver and spleen from the normal control fetus, whereas component $\mathrm{A}$ was absent in the liver and lungs of the abortus with Tay-Sachs disease (Fig. 2).

Thin-layer chromatography of brain gangliosides showed a sialic acid positive glycolipid with an $R_{f}$ value similar to $G_{2}$ (the Tay-Sachs disease ganglioside). This fraction comprised $22 \%$ of the total brain ganglioside sialic acid as compared with $8 \%$ in the normal control fetus and with $4.5 \%$ in the normal control child. In the Tay-Sachs disease child the $\mathrm{GM}_{2}$ fraction comprised $80 \%$ of the total ganglioside (Fig. 3).

TABLE I-Hexosaminidase A Activity* in Amniotic Cells, Leucocytes, and Urine

\begin{tabular}{|c|c|c|c|c|c|c|c|c|c|c|c|c|c|}
\hline \multirow[b]{3}{*}{ Case No. } & \multicolumn{3}{|c|}{ Prenatal } & \multicolumn{8}{|c|}{ Postnatal } & & \\
\hline & \multirow{2}{*}{$\begin{array}{l}\text { W'eek of } \\
\text { Pregnancy } \\
\text { of Amnio- } \\
\text { centesis }\end{array}$} & \multicolumn{2}{|c|}{ Amniotic Cells } & \multicolumn{2}{|c|}{ First Day } & \multicolumn{2}{|c|}{ First Month } & \multicolumn{2}{|c|}{ Second Month } & \multicolumn{2}{|c|}{ Sixth Month } & \multicolumn{2}{|c|}{ Twelfth Month } \\
\hline & & $\begin{array}{l}\text { Un- } \\
\text { cultured }\end{array}$ & Cultured & $\begin{array}{l}\text { Cord Blood } \\
\text { Leucocytes }\end{array}$ & Urine & $\begin{array}{l}\text { Peripheral } \\
\text { Leucocytes }\end{array}$ & Urine & $\begin{array}{l}\text { Peripheral } \\
\text { Leucocytes }\end{array}$ & Urine & $\begin{array}{l}\text { Peripheral } \\
\text { Leucocytes }\end{array}$ & Urine & $\begin{array}{l}\text { Peripheral } \\
\text { Leucocytes }\end{array}$ & Urine \\
\hline $\begin{array}{l}1 \\
2 \\
3 \\
4 \\
5 \\
6 \\
7\end{array}$ & $\begin{array}{c}25 \\
28 \\
20 \\
19 \\
18,20 \\
20 \\
18\end{array}$ & $\begin{array}{c}30 \\
22,25 \\
24 \\
27,28 \\
21 \\
27 \\
6\end{array}$ & $\begin{array}{c}56 \\
28 \\
27,33,35 \\
63,62,57 \\
51,53 \\
45 \\
1\end{array}$ & $\begin{array}{c}35 \\
60 \\
58 \\
34,38\end{array}$ & $\begin{array}{l}64 \\
57 \\
45\end{array}$ & $\begin{array}{l}39 \\
42 \\
64 \\
43\end{array}$ & $\begin{array}{l}68 \\
58 \\
36\end{array}$ & 59 & $\begin{array}{l}66 \\
66\end{array}$ & $\begin{array}{l}66 \\
45\end{array}$ & & $\begin{array}{l}68 \\
48\end{array}$ & \\
\hline Normal controls & $16-25$ & $\begin{array}{c}34(23-40) \\
n=12\end{array}$ & $\begin{array}{c}60(50-70) \\
n=10\end{array}$ & $\begin{array}{c}56(48-59) \\
\mathrm{n}=6\end{array}$ & $\begin{array}{c}66(56-70) \\
n=10\end{array}$ & & & & & & $\begin{array}{c}62(50-64) \\
n=10\end{array}$ & & \\
\hline
\end{tabular}

-Hexosaminidase A activity was calculated as a percentage of the total hexosaminidase activity in amniotic cells, leucocytes, and urine. 


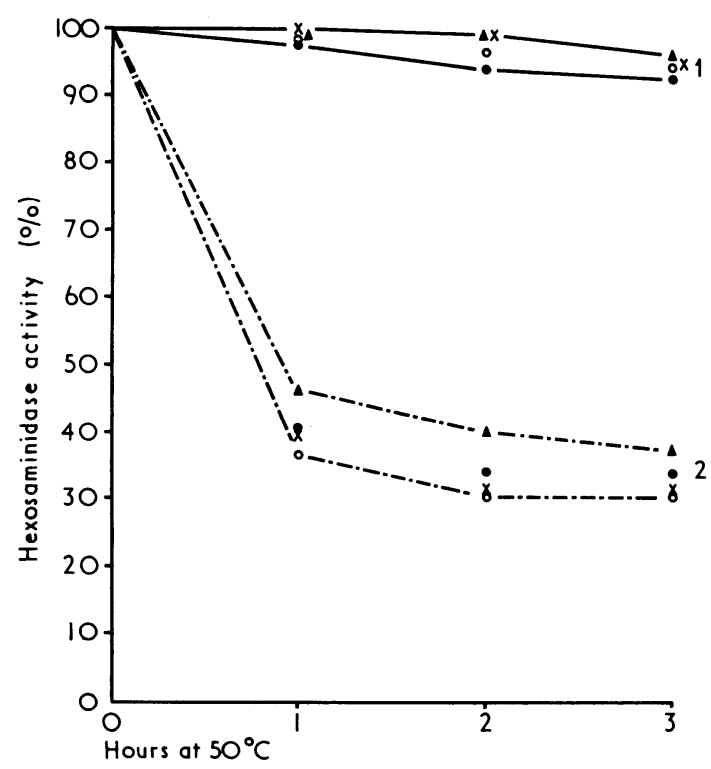

FIG. 1- Heat inactivation curves of hexosaminidase activity in homogenates of brain (O), spleen $(x)$, skin $(O)$ and skin fibroblasts $(\Delta)$ from two aborted fetuses. Curve 1 is that of an aborted fetus judged to have Tay-Sachs disease (Case 7). Curve 2 is that of a normal aborted fetus.

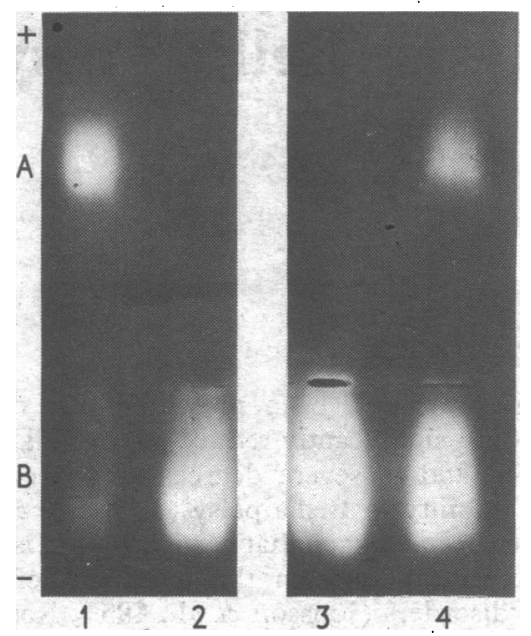
FIG. 2-Starch-gel electrophoresis of hexosaminidase from liver ( 1 and 2 )
and lungs ( 3 and 4 ) homogenates. Columns 2 and 3 are from the fetus and lungs ( 3 and 4 ) homogenates. Columns 2 and 3 are from the fetus A. Columns 1 and 4 are from a normal aborted fetus.

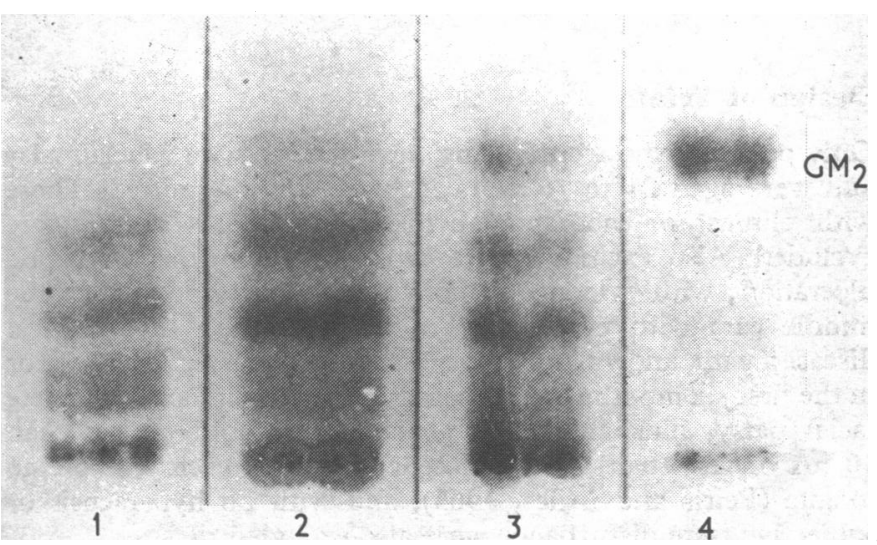

FIG. 3-Thin-layer chromatography of brain gangliosides sprayed with iodine. (1) Normal child. (2) Normal aborted fetus. (3) Fetus diagnosed as having Tay-Sachs disease. (4) Child with Tay-Sachs disease. Note the greater accumulation of the $\mathrm{GM}_{2}$ band in the Tay-Sachs disease fetus as compared with the normal fetus and normal child, but a lesser amount when compared with the Tay-Sachs disease child.
In order to examine the differences in activities obtained from cultured and uncultured amniotic cells (Tables I and II), hexosaminidase A activities of cultured, uncultured, and floating amniotic cells obtained from normal control women were measured and the proportions of dead cells in each category were estimated. These results are summarized in Table II.

TABLE II-Hexosaminidase A Activity* in Amniotic Fluid Cells of Normal Controls

\begin{tabular}{|c|c|c|c|c|c|c|}
\hline \multirow{3}{*}{$\begin{array}{l}\text { Case } \\
\text { No. }\end{array}$} & \multicolumn{6}{|c|}{ Amniotic Cells } \\
\hline & \multicolumn{2}{|c|}{ Uncultured } & \multicolumn{2}{|c|}{ Cultured } & \multicolumn{2}{|c|}{ Floating } \\
\hline & $\begin{array}{l}\text { Hexosamini- } \\
\text { dase A } \\
\text { Activity (\%) }\end{array}$ & $\begin{array}{l}\text { Dead } \\
\text { Cells } \\
(\%)\end{array}$ & $\begin{array}{l}\text { Hexosamini- } \\
\text { dase A } \\
\text { Activity (\%) }\end{array}$ & $\begin{array}{l}\text { Dead } \\
\text { Cells } \\
(\%)\end{array}$ & $\begin{array}{c}\text { Hexosamini- } \\
\text { dase A } \\
\text { Activity }(\%)\end{array}$ & $\begin{array}{l}\text { Dead } \\
\text { Cells } \\
(\%)\end{array}$ \\
\hline $\begin{array}{l}1 \\
2 \\
3 \\
4 \\
5 \\
6 \\
7 \\
8 \\
9\end{array}$ & $\begin{array}{c}40,38 \\
30,27 \\
28 \\
43 \\
21 \\
33 \\
35 \\
37\end{array}$ & $\begin{array}{l}74 \\
64 \\
79\end{array}$ & $\begin{array}{l}63 \\
59 \\
63 \\
55 \\
70 \\
51 \\
67 \\
72\end{array}$ & $\begin{array}{r}10 \\
0 \\
0 \\
10 \\
0 \\
0 \\
0 \\
5\end{array}$ & $\begin{array}{c}20,15 \\
10 \\
7 \\
9 \\
0 \\
10\end{array}$ & $\begin{array}{l}100 \\
100 \\
100 \\
100 \\
100 \\
100\end{array}$ \\
\hline Mean & $\mathrm{n} \stackrel{33 \cdot 15}{=}$ & $\mathrm{n} \stackrel{78}{=} 6$ & $\begin{array}{c}62.5 \\
n=8\end{array}$ & $\mathrm{n}=8$ & $\mathrm{n}^{9}=6$ & $\begin{array}{c}100 \\
n=6\end{array}$ \\
\hline
\end{tabular}

-Hexosaminidase A activity was calculated as a percentage of the total hexosaminidase activity.

While the mean of $33 \cdot 15 \%$ of hexosaminidase A activity was found in uncultured cells as compared with $62.5 \%$ mean in cultured cells, only $9 \%$ mean of hexosaminidase A activity was found in the floating amniotic cells, which were composed exclusively of dead cells.

\section{Discussion}

The large differences between the measured activities of hexosaminidase $\mathbf{A}$ in cultured and the uncultured amniotic fluid cells (Tables I and II) seems to be due to the fact that the cells obtained at amniocentesis are a mixture of many dead cells and a few living ones. The low hexosaminidase $\mathrm{A}$ activity in the dead cells (Table II) might be explained by the fact that form A of the enzyme is much more labile than form $B$ and converts partially to form $B$ at $37^{\circ} \mathrm{C}$ (unpublished preliminary results). Thus the level of hexosaminidase $A$ in the uncultured cells might depend on the proportion of living cells in the freshly obtained amniotic fluid and the results would not reflect the amount of hexosaminidase $\mathrm{A}$ in the developing fetus. Hence by testing the uncultured cells one cannot achieve a reliable prenatal diagnosis of the Tay-Sachs disease genotypes. Conceivably the loss of activity of form $A$ is not complete, nor does it occur immediately with the death of the cells. Therefore, there is no direct correlation between the proportion of dead cells and loss of activity (Table II). Furthermore, in extreme cases this phenomenon might lead to a false-positive diagnosis. The activities found in the cultured living cells seem to provide a much better and more reliable means of identifying the three genotypes.

In Cases 1, 4, and 5 the levels of hexosaminidase $A$ fell in the range found in cultured amniotic cells of normal controls and they are considered therefore to be homozygous normal. The activities of hexosaminidase $A$ in the cultured amniotic cells of Cases 2 and 3 were distinctly lower and the fetuses were presumed to be heterozygous. Case 6 also fell below the normal range but not as low as Cases 2 and 3. This fetus was also tentatively considered to be heterozygous. In sharp contrast to the previous six fetuses, Case 7 was considered homozygously affected with Tay-Sachs disease. The first six diagnoses were confirmed by later examinations of hexosaminidase A activity in the cord blood leucocytes, peripheral leucocytes, as well as in the urine. The results for the leucocytes in Cases 1, 4, and 5 
were in the range of normal, while those of Cases 2, 3, and 6 were in the range of heterozygotes (Padeh and Navon, 1971). The prenatal diagnosis of Tay-Sachs disease in Case 7 was likewise confirmed by the absence of hexosaminidase $\mathrm{A}$ activity in the fetal tissues, both by the heat inactivation method and by starch-gel electrophoresis and also by the almost threefold increase in amount of the $\mathrm{GM}_{2}$ ganglioside in the brain as compared with the normal fetus of the same age.

In conclusion, the procedure described above seems at present to be a most reliable method for the prenatal diagnosis of Tay-Sachs disease.

We are grateful to Professor D. M. Serr and his department for performing the amniocenteses; to Dr. S. Mashiah and Dr. S. Pollak for their care of the patients; to Professor S. Gatt and Mr. A. Hertzel for helping us in the analysis of the gangliosides; to Mrs. Z. Mark and Mrs. S. Sahar for their technical help; and to Dr. A. Adam and Dr. R. M. Goodman for their critical comments.

This work was supported in part by a grant from the Chief Scientist's Office, Ministry of Health, Israel.

ADDENDUM: After this manuscript had been submitted for publication an article by O'Brien et al. (1971) describing similar results was published. We have since tested amniotic cells from three additional obligatory heterozygous women for hexosaminidase A. In two cases no activity of hexosaminidase A was found in cultured amniotic cells, indicating a Tay-Sachs disease fetus. This diagnosis was again confirmed on examination of the fetal tissues after therapeutic abortion. In the third case an activity of $34 \%$ of hexosaminidase A was found in the cultured amniotic cells. This activity is distinctly lower than that observed in the normal range, and thus the fetus was considered to be heterozygous.

\section{References}

Gatt, S., and Berman, E. R. (1963). Fournal of Neurochemistry, 10, 43

Friedland, J., Schneck, L., Saifer, A., and Volk, B. W. (1970). Clinica Chimica.

Nadler, H. L. (1968). Biochemical Genetics, 2, 119.

Navon, R., and Padeh, B. (1971). Fournal of Pediatrics, (In Press)

O'Brien, J. S., Okada, S., Chen, A., and Fillerup, D. L. (1970). New England Fournal of Medicine, 283, 15.

O'Brien, J. S., et al. (1971). Science, 172, 61

Okada, S., and O'Brien, J. S. (1969). Science, 165, 698

Padeh, B., and Navon, R. (1971). Israel fournal of Medical Sciences, 7, 259.

Rattazzi, M. C., and Davidson, R. G. (1970). American fournal of Human Genetics, 22, 41 a (abstract).

Robinson, D., and Stirling, J. H. (1969). Biochemical fournal, 107, 321

Schneck, L., et al. (1970). Lancet, 1, 582.

Svennerholm, L. (1957). Biochimica et Biophysica Acta , 24, 604.

\title{
Comparison of Corticotrophin and Prednisolone in Treatment of Idiopathic Facial Paralysis (Bell's Palsy)
}

\author{
D. TAVERNER, S. B. COHEN, B. C. HUTCHINSON
}

British Medical fournal, 1971, 4, 20-22

\section{Summary}

In a controlled trial of the effects of intramuscular corticotrophin and oral prednisolone in the treatment of acute Bell's palsy 186 successive patients with idiopathic facial palsy were grouped for age and duration of palsy. They were then allocated at random to either corticotrophin or prednisolone therapy in pairs. The results were:

(1) 94 received corticotrophin and 32 developed some degree of denervation and 92 received prednisolone and 13 developed some degree of denervation $(P<0.005)$; (2) six of the corticotrophin group became severely denervated (less than $50 \%$ recovery) compared with none of the prednisolone group $(P<0.02)$; $(3)$ the best results were obtained in the younger patients (less than 45 years old) treated on the first or second day of palsy; and (4) side effects were minimal.

It is concluded that oral prednisolone is the treatment of choice for idiopathic facial (Bell's) palsy.

\footnotetext{
Department of Electromyography, General Infirmary, Leeds

D. TAVERNER, M.D., F.R.C.P., Consultant Physician

S. B. COHEN, M.B., M.R.C.P., Senior Medical Registrar (Present address : Clatterbridge Hospital, Wirral, Cheshire)

B. C. HUTCHINSON, M.B., CH.B., Medical Registrar (Present address: St. James's Hospital, Leeds)
}

\section{Introduction}

Evidence has previously been presented that daily injections of corticotrophin significantly reduce the overall incidence both of denervation and of severe degrees of denervation carrying permanent disability in Bell's palsy (Taverner et al., 1966). It has sometimes been claimed that corticotrophin is more effective than oral steroid therapy in the treatment of inflammatory neurological disorders (Jönsson et al., 1951; Ross et al., 1958; Miller et al., 1961) but firm supporting evidence is lacking. After a suggestion from Professor $\mathrm{H}$. Miller (personal communication, 1966) it was decided to compare these two agents in the treatment of Bell's palsy. The results of this trial are now reported.

\section{Design of Trial}

Only patients who were having their first attack of facial palsy and were aged 21 to 70 years inclusive were admitted. Those with clinical or laboratory evidence of herpes zoster were excluded. Also excluded were those with a history of peptic ulceration; with evidence of active infection, especially of the middle ear; with evidence of more widespread neurological disease; with known hypertension; with diabetes mellitus; or in the first six months of pregnancy. Patients with an incomplete facial palsy, plus an anodal galvanic threshold of less than $10 \mu \AA$ or less than $5 \mu \AA$ difference between each side of the tongue (Peiris and Miles, 1965), and with no hyperacusis or subjective taste disturbance were also excluded.

The time of onset of the palsy was taken as the day that weakness of the face was first noticed. This was counted as day 1 and patients were admitted up to day 4 .

Patients were entered chronologically into four groups; two 